\title{
Blater Power Relation as a Symbol in the Political Seat Battle in Bangkalan
}

\author{
Eni Syafitri ${ }^{*}$, Agus Machfud Fauzi $^{2}$ \\ ${ }^{1}$ Universitas Negeri Surabaya \\ ${ }^{2}$ Universitas Negeri Surabaya \\ *Corresponding Author. Email: eni.18030@mhs.unesa.ac.id
}

\begin{abstract}
Madura is famous for the dominance of a very popular religion, the position of religion is divided into several clusters that are members of the socio-economic community. These classes include the kyai and the blater who often have an important and major role in all aspects including political activities, who work as mapping the course of the political struggle in Madura. One form of dominative politics that is implemented uses religious elements of kyai and blater. The phenomenon that occurs in the political elite in fighting for power. The purpose of this study is to describe the existence of a blater in a political struggle to get a seat. This study uses a qualitative method because it is considered very relevant to the theme that discusses politics. The theoretical concept used as an analytical tool in this research is the concept of power according to Michael Foucault, who explains power as the greatest domination in the room where power operates which is recorded in the highest institutional structure in politics. The researcher's initial assumption is that the existence of kyai and blater determines the dynamics of politics in fighting for seats of power in the local area.
\end{abstract}

Keywords: Power, Politics, Blater, Kyai.

\section{INTRODUCTION}

As a country that was a former colony of other countries, there is a system that tends to have similarities. The history of the circulation of Indonesian leadership has a long series of events. Almost every regime change that has been passed has a different characteristic, how to lead during his tenure. Characteristics or traits that are displayed as a form of character or basic leadership model adopted. It is recorded throughout history that during the colonial era the wheels of Indonesian leadership were under the control of foreign countries as invaders. At that time the conditions were so astonishing that it was colored by exploitative politics, where slavery and injustice, similar things happened, did not escape the goal of economic interests and power [1].

Soekarno's fall from the rule of the old order led to the emergence of Indonesia in a new era spearheaded by Suharto, which can be said to be the dark period with his centralized leadership model. Over time, the reforms moved towards the exit to be replaced by a democratic system [1]. However, at this time Indonesia has undergone a dynamic change as evidenced by the freedom of the people from the intervention that was previously implemented. The series of political mobilizations that occur are different, namely the structural and cultural models. The New Order leadership model was colored by violence in the sense that freedom was still being restrained and demands were more. However, democracy is more about religious values in substance. Thishappens universally and is widely known by the general public. The same thing is increasingly happening in Madura, which has almost the same problem that reflects the condition of the country atlarge, namely political mobilization which is related to the existence of the blater [2]. In Madura itself, the blater have a strong position, just like the position of the kyai and other religious figures. The construction of the blater community has been ingrained long ago. This happens because they have physical strength by relying on local wisdom [3]

Relying on physical and mental strength can guarantee protection and safety for the community. This is a sign or symbol of peace before the struggle 
for a seat, which is often colored by slashing or in Madurese terms, "carok" which dominates these champions. As happened a few weeks ago in the carok case at the time of determining the village head election committee, this case occurred in the city of Bangkalan during the selection of the committee, allegedly due to competition between supporters or the term opposition (Abd Hanan, 2019). However, in this case, the position of kyai and religious leaders as cultural symbols that rely on the value of symbols in religious networks and local culture is also important. In the map of the local political battle of Madura, especially the city of Bangkalan, which synergizes between the blater, kyai and religious organizations that are always glorified in Madura, namely NU (Nahdatul Ulama).

Based on the problems above, a deeper study can be carried out using case studies in the socio-political field, how the dynamics of power as a symbol of success in political battles, there is synergy from several groups. Therefore, the above problems can be answered through this research as a crucial solution to the problem, especially in the realm of local leadership mobilization, especially Bangkalan. Based on the above background, the formulation of the problem is as follows: 1 . What is the position of the blater in the battle for political seats in Bangkalan city? 2. How is the synergy between the blater and the power of the kyai in the battle for political seats?

The benefits of research can contribute to the scientific angle of sociology, especially regarding political themes and provide full references and become the background for further research. As well as being able to provide understanding to the community, especially the government related to socio-cultural conditions which are still thick with the adnaya blater symbol as the second position after the kyai.

As for several previous studies that were used as references or materials for conducting research, the function of previous research was a starting point in conducting research as well as being a comparison between the past and this research. The first research by Ishaq Abdussalam explained that the dominance of kyai and blater in the election of the Bangkalan regent influenced the community in making their choice. The symbol of the kyai who is played as one of the kholil breeds is deeply rooted in the daily life of the Bangkalan people in particular. In addition, there are two dimensions of blater that can intimidate the community through their power and determine obedience to the orders of a kyai. The second study by Shohebul Umam from the results of his research stated that there was an imbalance of power relations in village politics. So far, no actor has been able to stop the culture and political pattern ofpower relations which in the end gave birth to social exclusion despite the role of the kyai. Who has been believed to be an individual who can create changes in mastery. The third research by Mohammad Kosim, the result of his research, is that kyai and blater are two local elites in the socio- political life of the Madurese community. Kyai is a spiritual agent and is very influential in all aspects including politics and blater occupies the number one seat of courage to rely on physicality and personality in his sociopolitical struggle.

\section{METHODS}

This study uses a qualitative approach with a descriptive research design. The reason the researcher took this design was because it was possible to obtain the information that could not be obtained by the presence of the researcher in the field. So this method is the right method and can provide a comprehensive study related to the existence of the blater in its role as a determinant of the direction of politics, especially in Madura.

This research was conducted in a subdistrict in the city of Bangkalan. The reason the researcher chose this location, apart from the distance between the research sites, was also because this place became the place for the practice of blater in the context of political seat struggles, especially during the election of regents and village heads. Maybe it will be different from other places that have their own characteristics. The subjects in this study were the community or village officials who took part in the pace of politics.

The technique used in this study there are 3 stages including Observation, Interview and Documentation. After conducting observations and interviews, the next step is to analyze the results obtained. So that the data can be analyzed by data display/data presentation, verification and analysis using theory.

\section{Theoretical review}

Power relations in Foucault's view rely on the existence of a relationship that does not take place in a balanced way. The power relation is an asymmetric form of power in which the subject who is dominated has limited space to maneuver or determine the choice of an action. True power according to Foucault is not understood as a mechanism that ensures the submission of citizens 
to the state. Thus a state or legal institution that presupposes external domination or control over individuals or groups [4].

"Power is always understood as something that perpetuates the power relations, which forms a chain or system of relations or which isolates their space from others from power relations". Therefore, Foucault as the owner of power refers to the totality of the structure of action to direct the actions of independent individuals. Power is exercised over those who are in a position to vote and is shown to influence their choices (Michael Foucault, n.d.). Foucault also distinguishes several power relations into three parts, namely:

1. Power relations as a strategic game between independent parties. Power at this level involves parties who have independence so that no domination is exercised in this power relation. Purely from a strategy game. In this case, the concept is more about the power to determine the relationship between partners in the action ensemble.

2. Power relations as domination where the form of practice of power that has implications for giving birth to a situation in which the domain of choice of the subject's actions are dominated is so limited. Domination itself refers to asymmetric power relations in which people can be subordinated to

have little space, so that there is very limited freedom in action.

3. Relations as a form of government, that the conception of government is primarily associated with the concept of leading in the sense that it directs or controls actions that refer to the exercise of power over other parties. Starting from the implementation of government in reciprocity.

\section{RESULTS AND DISCUSSION}

\subsection{Overview of the research site}

West Sukolilo Village, Labang District, Bangkalan Regency is a village where the community has a fairly high tolerance. This is indicated by the presence of more than 20 places of worship, which consist of 10 mosques, 5 breaking buildings.

This West Sukolilo village has a total of 1,086 households where the male population is 4002 people and the female population is 4035 people. There are 10 types of social institutions consisting of PKK, RT, RW, Youth Organizations, Farmers' Groups and BUMDes, women's organizations, youth organizations and foundations. Most of the villagers make a living as farmers and fishermen because they are geographically close to the Madura Strait.

\subsection{Blater Position}

The term blater is especially well known among the people of West Madura, namely (Bangkalan and Sampang). This term refers to the figure of a strong person in the village who can provide physical safety protection to the community. The blater figure who has now become a legend among the Madurese community is Pak Sakera, who has failed to dare to defend the little people/herein people from the cruelty of theinvaders. Pak sakera's words that are still famous when he was about to be hanged by the Dutch were "Bastard Gupermen, ja' an combinea, bender sengko' mate, tape enga', sittong sakera mate saebu sakeraa tombu pole".

Another term for blater is bajinga. However, in the view of the Blater community, the status of clothes is seen as inferior. Bastards are known for being arrogant, rude, arrogant and like to make trouble. The activities inherent in rogues are gambling and playing with women, robbing and other criminal acts. Both characteristics may or may not be the same as blaster and may or may not be. But a little of the picture is already legible.

The space of a blater can be reflected when there are traditional entertainment events, one of which is remoh. Through this forum, the blaters come together as one where chemistry can be well established by showing their respective strengths. In addition to this trivial event, it usually also occurs in cockfighting and frequent sapeh.

Culturally, the role and influence of the blater is usually influenced by two things, namely the ability in the science of kanugaran, martial arts and immunity as well as a large network of subordinates (Djatmiko, 2019). The most striking role is when it is reflected in the successful carok and preventing violent conflicts. Blater people are increasingly respected because they are involved in criminal acts so that apart from being respected by the community, they are also respected by state officials, for example the police and legal authorities.

Blater's appeal is quite strong as an elite group at the village level. The power of the village lies with the group, something similar can be very useful in critical situations such as violence, 
robbery and theft. Usually this group is in various aspects, for example in business, so it is not enough to believe in the existence of security guards, but in the blater especially because they are trusted.

In the political field, the involvement of the blater is also very visible, and the position of the blater is well understood by most of the people who are very familiar with it and especially during the election of the village head. Between blater and pilkades arena like ants and sugar. Where there are Pilkades, there is a Blater. Blater's involvement was really planned, because it determines the direction of politics, including the success of one candidate pair. It is undeniable that there is also prestige and security in the running of an election. In fact, the candidate pair does not always rely on the blater to guard it, but if it does not come from the blater circle, it must be able to get along with them. In the case of pilkada and pilkades, party leaders and their team members often use the services of this blater to calm the fight due to an unexpected conflict. Bearing in mind that in the past on the island of Madura in history there were many blater involved so that it is still warm to this day and has become a habit and interest in an event, including political events in Madura, especially Bangkalan (Kosim, 1998). The position of the blater has several levels which is reflected in the village of sukolilo which is only localization and the space is limited, and it is possible to synergize with other blaters.

\subsection{Unhealthy Seat Fight}

The Pilkades in Sukolilo Barat village, Labang sub-district, is like politics in general, which relies a lot on all means to get a seat of power. Residents were targeted by the village government during the pilkades. Many motives are carried out by the village head to achieve common interests.

Madura, with its ecological and sociological movements, forms a bound structure in which the growth of this blater community as a social force of society, especially in rural areas is thus a product of the social community (Rakhmawati, 2015). In the midst of the economic downturn and capitalist development that does not empower the community, the theft of land ownership from the upper class is referred to as the hero, namely the blater. This is a form of resistance or protest that is carried out in a covert manner.

Politics in Madura is known for its violence and very high religiosity. when in fact the two things have different meanings. But what is more dominant is the presence of violence where if one's life is close to violence, it will be far from ascetic.

Based on the interviews conducted, the community knows this and understands so that in the findings of the data obtained, the community acts as followers only. remembering that apart from being able to read the situation of the blaster, he was also able to gather the masses. So that the use of capital is very important in any case, especially in this political interest.

The power of blater has an influence on people's submission to their instructions, fighting the batter is the same as looking for trouble. If there are people who dare to criticize, especially to the point of disobeying, then it is a sign that the person will not be safe and at the very least will have a restless life.

\subsection{The community's response is the existence of blater}

Apart from the elite who got a strong position in society. In certain contexts, its existence does not have to be acknowledged, but in the circulation leadership is always involved in displaying the running of politics and becomes a characteristic.

5 out of 10 informants admitted that "they need the presence of a blater because when one of the candidate pairs does not win a seat, there will be conflict/bloodbath between supporters". Therefore the presence of a blaster is highly desirable. Each village has its own hero and it is certain that it will run smoothly.

Voting rights may not be purely democratic because there is an element of attachment. Community participation is undervalued because it can be bought. The existence of hegemony that occurs between the village government in the community. One of the informants said that "money ploy is used to weaken the people" meaning here is that when we do not accept the contribution, later the blater will use other means to carry out other interests.

The functions and uses are the same between the blater and ordinary people, but the assumptions and assumptions are very large in carrying out based on their position as local champions, some choose to go into the field and some go to the village head and some even just maintain security.

In the context of the Pilkades he occupied an intellectual position so that he held a strong 
constraint in the course of the event. For the champions, the Pilkades event is a prestigious event, so in this case it shows its existence as a respected person, and there is a betting process based on the candidate they favor.

The Pilkades event became a momentum for the blater in doing gambling and the challenge was networking and relationships. The bigger the relationship, the higher the public's reluctance. The event determines whether or not the blater wins. In this case the village head/klebun must have a strong relationship with the blater and build closeness. So don't be surprised if those who get seats are from their group.

Many people assume that they have to follow instructions just to be safe. The form of approach taken to the community is diverse and different from the kyai's strategy, the informant explained that "making a romantic relationship that can control and oversee the course of political cycles with money and promises security for the community".

\section{CONCLUSION}

Based on the findings obtained can be linked and analyzed using the concept of power from Michael Foucault. The power space cannot be separated from the strong hegemony and deliberately built by the upper class. The phenomenon of gaining seats and power can be analyzed, "Power is exercised over those who are in a position to vote and is shown to influence their choices" (Duineveld \& Dix, 2011).

The power of the people is in the blater and this is indeed in line with the thinking of Michael Foucault who says that power is shown to influence people's choices, in this case the Pilkades becomes the momentum of this theory.

In the concept there are 3 types that distinguish power according to Foucault, namely: power as a strategy of the independent party in the sense that here is a blater who has full power over his character to buy the people's vote because it promises something, namely security. The people as the weakest arena of domination is something that is unfortunate. The second is power as a practice for confined spaces. In this case, the study is the small people, with the practice of sound politics people have no value in the sense that they can be bought and leveled. So that truly pure democratic participation is not real. There is still interference from others.

\section{ACKNOWLEDGMENT}

I always express my gratitude to all supporters, especially the supervisors who always provide evaluations and assessments. To the informants, namely the village community, for the help in answering I say many thanks without limits. Especially for my guide until now, namely my parents (mother and father) who always give blessing from time to time. Hopefully this article can be helpful for readers and provide new knowledge that is linear.

\section{REFERENCES}

[1] A. Khoiri, "Kontrol Politik Kyai dan Blater dalam Pelaksanaan Pemilu; Kajian Kelemahan Ketentuan Hukum Pemilu Menghadapi Rezim Kembar Politik di Madura Political Control of Kyai and Blater in The Election Implementation: The Study of The Weakness of Election Law Pr," 1945.

[2] Ishaq Abdussalam, "Reproduksi Kekuasaan Kyai dan Blater di Kabupaten Bangkalan," Prodi Sosiol. FISIB, 2012.

[3] Z. Laily, "Eksistensi Blater Bagi Masyarakat Desa Katol , Kecamatan Gegger , Kabupaten Bangkalan,” vol. 01, no. 01, pp. 1-20, 2020.

[4] K. A. Abd Hanan, "HEGEMONI RELIGIOKEKUASAAN DAN TRANSFORMASI SOSIAL Mobilisasi Jaringan Kekuasaan dan Keagamaan Kyai dalam Dinamika Sosio-Kultural Masyarakat Madura,"Sos. Budaya, vol. 16, no. 1, 2019.

[5] L. Cremonesi, O. Irrera, D. Lorenzini, M. Tazzioli, and O. Ew, "Foucault and the Making of Subjects Edited by," 2016.

[6] W. P. Djatmiko, "Rekonstruksi Budaya Hukum Dalam Menanggulangi Carok Di Masyarakat Madura Berdasar Nilai-Nilai Pancasila Sebagai Sarana Politik Kriminal," J. Huk. Progresif, vol. 7, no. 1, p. 40, 2019.

[7] M. Kosim, “(Elite Lokal dalam Masyarakat Madura)," 1998.

[8] F. N. Rakhmawati, Perempuan Madura:"Mangada" ditengah Himpitan Budaya Matrilokal dan Kekuasaan Patriarkat. 2015.

[9] M. Duineveld and G. Dix, "Power and discipline in transitions: Michel Foucault Power and discipline in transitions : Michel Foucault," no. July 2015, 2011. 